\title{
Haemolytic Anaemia in Indian Childhood Cirrhosis
}

\author{
A. PERKASH, A. NAIR, R. BHORCHI, and B. N. S. WALIA \\ From the Institute of Postgraduate Medical Education and Research, Chandigarh (India)
}

\begin{abstract}
Perkash, A., Nair, A., Bhorchi, R., and Walia, B. N. S. (1971). Archives of Disease in Childhood, 46, 45. Haemolytic anaemia in Indian childhood cirrhosis. Fifty-five patients with Indian childhood cirrhosis were investigated for the occurrence of haemolysis and for its possible underlying mechanisms. Increased haemolysis was present in $76 \%$ of patients, and was severe in $12 \%$. The degree of anaemia was not always proportional to the severity of haemolysis. No single factor accounted for haemolysis. Evidence of hypersplenism was present in only $7(13 \%)$ patients. The haemolysis appeared to be more severe in patients with advanced liver disease. Evidence for autoimmune haemolytic anaemia was found in $27 \%$ of patients. No relation was seen between the degree of haemolysis and hypercholesterolaemia. These findings are compared with those reported in adult patients with cirrhosis of the liver.
\end{abstract}

Increased haemolysis frequently occurs in adult patients with cirrhosis of the liver. Evidence regarding reduced red cell survival in this condition has been reviewed by Dacie (1967). The factors believed to contribute to haemolysis are hypersplenism (Berman et al., 1949; Huang and Wang, 1949; Jones et al., 1955; Zieve, 1966), and severe liver cell injury leading to damage to red cells (Hyman and Southworth, 1951) and hyperlipaemia (Zieve, 1966). This paper reports the occurrence of haemolysis in children with Indian childhood cirrhosis and the role of various factors in its causation.

Indian childhood cirrhosis (Liver Diseases SubCommittee, 1955; Achar, Raju, and Sriramachari 1960) is a disease peculiar to infants and young children of Indian origin. It is characterized in the early stages by enlargement of the liver, which is hard, and usually also of the spleen, with ascites and jaundice in the later stages. The onset is insidious, course generally progressive, and termination usually fatal. Histologically the lesion consists of liver cell degeneration with replacement fibrosis, the process being either episodic or relentless and continued. Regeneration of liver cells at best is ineffective. The aetiology is unknown.

\section{Material and Methods}

Fifty-five children with Indian childhood cirrhosis aged between 8 months and 12 years were studied. The

Received 9 May 1970. diagnosis was made on the basis of clinical history and physical examination. The following tests were done to assess the severity of liver dysfunction; serum proteins, prothrombin time (Quick's one stage), direct and indirect serum bilirubin, and zinc turbidity test. Liver biopsy was attempted when the prothrombin index

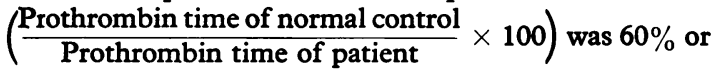
above. Histopathological confirmation of the diagnosis of Indian childhood cirrhosis was available in 20 patients (18 biopsy and 2 necropsy). Liver biopsy was done with the Vim-Silverman needle.

Haematological investigations included haemoglobin estimation (oxyhaemoglobin method), packed cell volume, reticulocyte count (on dry films), total and differential leucocyte count, platelet count (direct method with light microscope), Heinz body test, osmotic fragility, urine haemoglobin, urine haemosiderin, fetal haemoglobin, test for sickling, and paper electrophoresis of haemoglobin at $p \mathrm{H} 8.6$ by the methods described by Dacie and Lewis (1963). The plasma haemoglobin was measured by the benzidine method (Dacie and Lewis, 1963) on blood samples collected with special care and centrifuged immediately after collection to avoid haemoglobin release in vitro. Reticulocyte counts were expressed as the observed percentage.

Blood smears were made from venous blood immediately after collection, air-dried, and stained with Leishman stain. Bone-marrow was aspirated by Salah needle. Iliac crest was punctured in the younger children and the sternum in older ones. The marrow films were stained with Leishman stain and by the Prussian blue method for stainable iron.

The tests performed for red cell antibodies included 
(1) direct and indirect Coombs test, using fresh normal group $\mathrm{O}$ Rh positive cells at $37^{\circ} \mathrm{C}$. The Coombs serum used was rabbit antihuman globulin serum prepared against whole human serum. Immunoelectrophoretic studies of this serum revealed activity against both $7 S$ and 19S fractions. Antitransferrin and anticomplement activity was not determined. (2) Cold haemolysins with fresh normal group ' $O$ ' cells according to methods described by Dacie and Lewis (1963). None of the patients investigated had received blood transfusion previously. Serum cholesterol was estimated by the method of Schoenheimer and Sperry (1963)

\section{Results}

Biochemical evidence of increased haemolysis. At the time of admission all 55 patients were anaemic, with $\mathrm{Hb}$ values below $12 \mathrm{~g} / 100 \mathrm{ml}$. Anaemia was mild (Hb more than $10 \cdot 1 \mathrm{~g} / 100 \mathrm{ml}$ ) in 22 , moderate $(6 \cdot 1-10 \mathrm{~g} / 100 \mathrm{ml})$ in 25 , and severe $(6 \mathrm{~g} / 100 \mathrm{ml}$ or less) in 8 children.

Haemoglobinaemia ranging from 10 to $61 \mathrm{mg} /$ $100 \mathrm{ml}$ was found in $44(80 \%)$ patients (normal range $0-8 \mathrm{mg} / 100 \mathrm{ml}$ ). Mild to moderate increase in the serum unconjugated bilirubin was seen in $\mathbf{5 2}$ patients. Bilirubin value of $0 \cdot 5-1 \mathrm{mg} / 100 \mathrm{ml}$ was present in 16 patients, between $1 \cdot 1$ and $5 \mathrm{mg} / 100 \mathrm{ml}$ in 25 patients and $5.1 \mathrm{mg} / 100 \mathrm{ml}$ or above in 11 patients (normal range $0-0 \cdot 5 / 100 \mathrm{ml}$ ). Haemoglobinuria in trace amounts was found in only 2 patients. However mild to moderate haemosiderinuria was seen in $31(66 \%)$ children. In all patients with haemosiderin in urine other evidences of haemolysis were also present.

Haemopoietic cellular response. Indirect indications of haemolysis, such as reticulocytosis, leucocytosis, presence of nucleated red cells in the peripheral blood, and erythroid hyperplasia in the bone-marrow were looked for. Reticulocytosis was seen in 42 out of $55(76 \%)$ patients. Nucleated red cells up to 6 per 100 leucocytes were seen in the peripheral blood films of $15(27 \%)$ children. These consisted of intermediate and late erythroblasts. Of 55 patients, 12 showed erythroid hyperplasia in the bone-marrow. Erythropoiesis was normoblastic in 34, macronormoblastic in 17, and megaloblastic in 4 patients.

Leucocyte counts were normal for the chronological age of the children in 31 patients, but there was moderate leucocytosis in 18 patients, of whom 6 showed leukaemoid reactions, with total leucocyte counts of $30,000 \mathrm{~mm}^{3}$ or more, and myelocytes and metamyelocytes constituting $20-30 \%$ of the leucocytes.

Red cell abnormalities. Heinz body test was negative in all instances. Moderate to severe poikilocytosis was seen in the peripheral blood films of $35(63 \%)$ patients. This presented in the form of acanthocytosis, burr cells, irregularly contracted cells, and schistocytosis in 37 patients (65\%). Spherocytosis was seen in 48 patients. In the majority of them it involved only 10 to $15 \%$ of red cells in any one blood film. However, in 4 patients the spherocytosis involved 50 to $75 \%$ red cells. Small agglutinates or erythrocytes were seen in 6 patients.

Osmotic fragility was normal in 37 patients but a significant tail of excessively susceptible cells was seen in the osmotic fragility curve of 10 and an obvious increase in 7 patients.

The fetal haemoglobin content was within normal range for the age of the patients. Tests for sickling were uniformly negative and haemoglobin electrophoresis did not reveal any abnormal haemoglobin.

Grading of degree of haemolysis. An attempt was made to assess the extent of haemolysis by grading it into four grades on the basis of the biochemical and haematological data (Table I). Each of the 8 criteria used was arbitrarily assigned

TABLE I

Criteria for Grading and Degree of Haemolysis

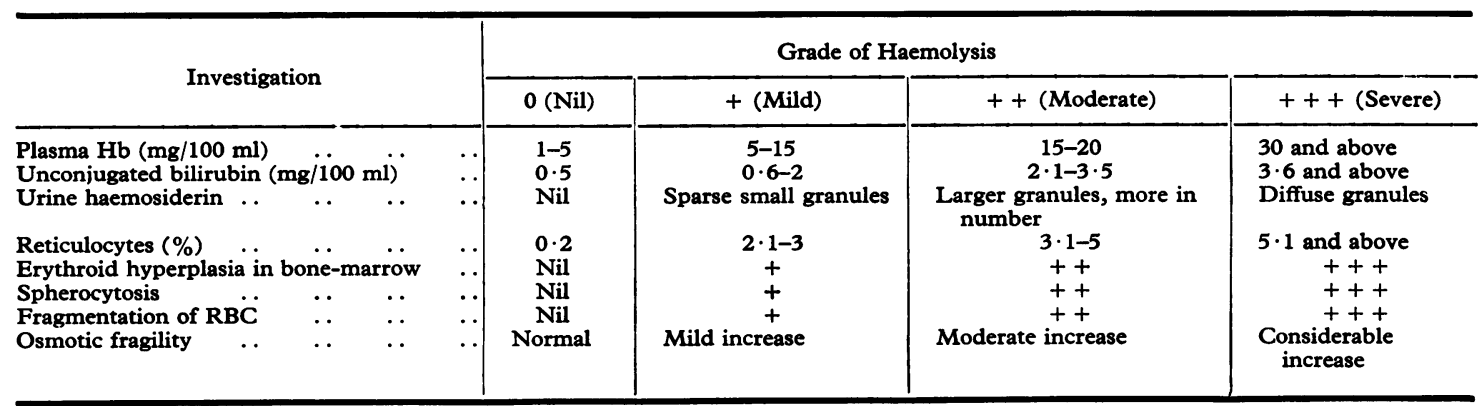




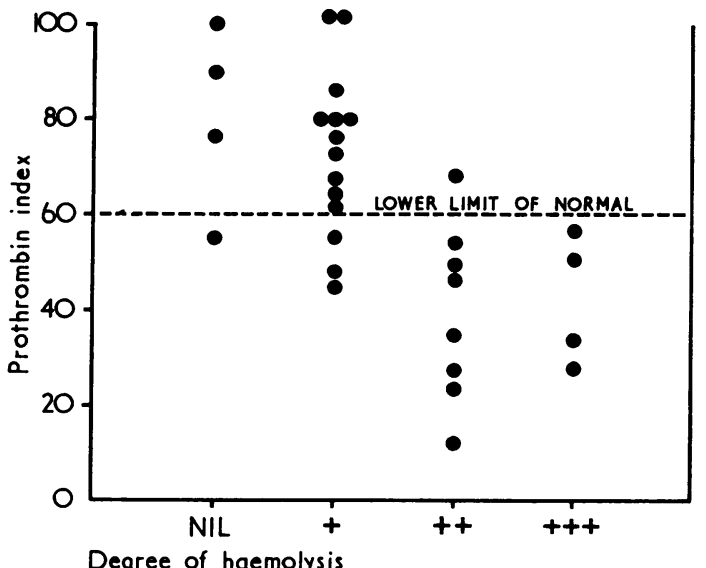

FIG. 1.-Degree of haemolysis in relation to prothrombin index.

a value of 0 to 3 . The mean of the value thus obtained in each patient gave the final rating for the degree of haemolysis observed. The analysis of the patients according to this grading is shown in Table II.

TABLE II

Degree of Haemolysis in 55 Patients with Indian Childhood Cirrhosis

\begin{tabular}{|c|c|c|c|c|c|c|}
\hline \multicolumn{5}{|c|}{ Degree of Haemolysis } & No. of Patients & Percentage \\
\hline $\begin{array}{l}0 \\
+ \\
++ \\
+++\end{array}$ & $\begin{array}{l}\ddot{.} \\
\ddot{*} \\
\dot{*}\end{array}$ & $\begin{array}{l}\ddot{ } \\
\ddot{*} \\
\cdots\end{array}$ & $\begin{array}{l}\cdots \\
\cdots \\
\cdots\end{array}$ & $\begin{array}{l}\cdots \\
\cdots \\
\cdots\end{array}$ & $\begin{array}{r}13 \\
21 \\
14 \\
7\end{array}$ & $\begin{array}{l}23 \\
38 \\
25 \\
14\end{array}$ \\
\hline
\end{tabular}

Many patients manifesting severe haemolysis were in advanced hepatic failure. Three died in hepatic coma a few days after investigation. Moderate and severe haemolysis was seen only in children below the age of 2 years.

Haemolysis in relation to liver pathology and function. The histopathological grading of

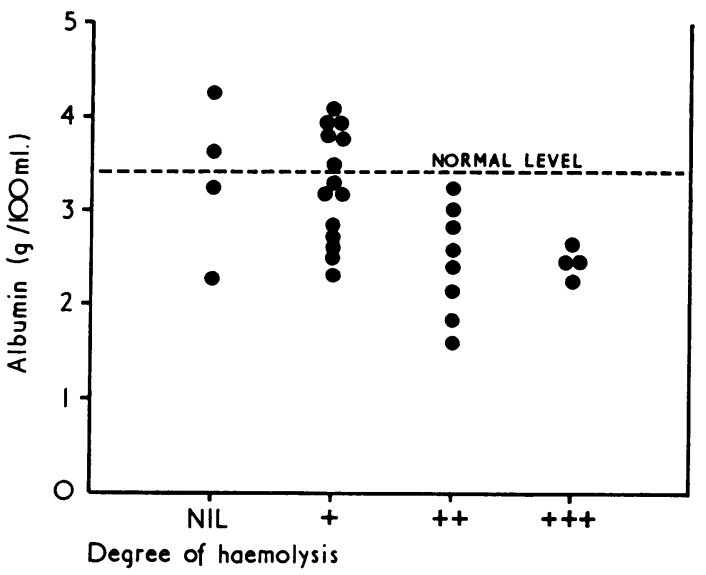

FIG. 2.-Degree of haemolysis in relation to serum albumin.

the severity of cirrhosis did not correlate with the severity of haemolysis observed. However, in 30 patients in whom the relevant data were complete, a positive correlation was found to exist between the prothrombin index and serum albumin on the one hand and the degree of haemolysis on the other. In general, the haemolysis tended to be severe in patients with lower prothrombin index and low serum albumin (Fig. 1 and 2).

Splenomegaly and haemolysis. Splenomegaly was observed in 50 patients. As evidence of hypersplenism anaemia was accompanied by thrombocytopenia in 7 patients and leucopenia as well in one (Table III). The splenic enlargement in these patients varied from 1 to $7 \mathrm{~cm}$ below the costal margin and the bone-marrow was either normal or hypercellular.

Antierythrocyte antibodies and haemolysis. A preliminary screening of all patients was done for the presence of antierythrocyte antibodies. The presence of either a red cell agglutinin or incomplete

TABLE III

Haematological Findings in 7 Patients with evidence of Hypersplenism

\begin{tabular}{|c|c|c|c|c|c|c|}
\hline Case No. & $\mathrm{Hb}(\mathrm{g} / 100 \mathrm{ml})$ & Leucocytes/mm $\mathrm{m}^{3}$ & Platelets $/ \mathrm{mm}^{3}$ & Reticulocytes (\%) & $\begin{array}{l}\text { Marrow } \\
\text { Cellularity }\end{array}$ & Haemolysis \\
\hline $\begin{array}{l}1 \\
2 \\
3 \\
4 \\
5 \\
6 \\
7\end{array}$ & $\begin{array}{l}9 \cdot 2 \\
6 \cdot 1 \\
6 \cdot 8 \\
4 \cdot 4 \\
2 \cdot 5 \\
5 \cdot 0 \\
4 \cdot 9\end{array}$ & $\begin{array}{r}9,200 \\
16,000 \\
96,000 \\
4,800 \\
14,500 \\
10,500 \\
8,800\end{array}$ & $\begin{array}{l}90,000 \\
68,800 \\
67,200 \\
34,800 \\
47,000 \\
20,600 \\
46,700\end{array}$ & $\begin{array}{r}6 \\
5 \\
8 \\
7 \\
18 \\
4 \\
1\end{array}$ & $\begin{array}{l}\text { Normal } \\
\text { Normal } \\
\text { Increased } \\
\text { Increased } \\
\text { Increased } \\
\text { Normal } \\
\text { Increased }\end{array}$ & $\begin{array}{c}++ \\
++ \\
+++ \\
+++ \\
+++ \\
+ \\
-\end{array}$ \\
\hline
\end{tabular}




\section{Haemolytic Anaemia in Indian Childhood Cirrhosis}

antibody was detected in 40 out of 55 patients. The observations on the significantly positive tests are given in Table IV.

TABLE IV

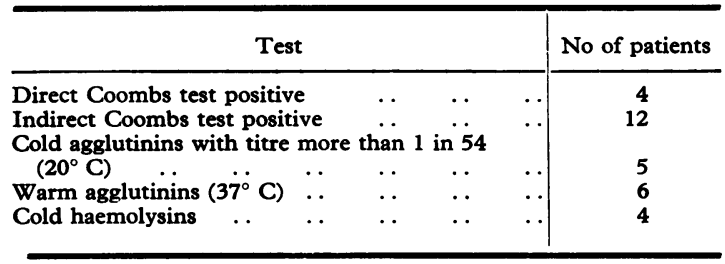

The relation between the presence of antierythrocyte antibodies and haemolysis is shown in Table V. Positive Coombs test (either direct, or indirect or both) was associated with spherocytosis and variable increase in osmotic fragility along with grade ++ or +++ haemolysis in 8 patients (Cases 1, 2, 3, 13, 14, 15, 16, 17). In 3 patients (Cases 5, 6, and 18) Coombs test was positive but other findings were variable and no haemolysis was detected. Thus, the degree of haemolysis did not always correlate with the presence of red cell antibodies and/or the strength of reaction that they gave. However the serological and other red cell abnormalities suggested the presence of autoimmune haemolytic anaemia in at least 15 patients.

Serum cholesterol and haemolysis. Serum cholesterol above $250 \mathrm{mg} / 100 \mathrm{ml}$ was seen in 8 patients.
No correlation was found between serum cholesterol levels and grade of haemolysis.

\section{Discussion}

In this study increased haemolysis was demonstrated in $76 \%$ of the patients with Indian childhood cirrhosis. In the majority of them the haemolytic component of anaemia was not suspected clinically, since both anaemia and jaundice were attributed to liver disease. Further, in the presence of liver disease, hyperbilirubinaemia and increased urobilinogen excretion in the urine and stools cannot be relied upon as indices of increased haemolysis. In the present series it is uncertain how far the rise in the unconjugated bilirubin was due to increased haemolysis or to liver dysfunction. However, in the majority of the patients with raised serum unconjugated bilirubin, the plasma haemoglobin was also increased. Haemoglobinaemia being a reliable index of increased intravascular haemolysis, it can be assumed that at least part of the hyperbilirubinaemia was due to increased haemolysis. Significant haemoglobinaemia in adult patients with cirrhosis of the liver has been reported only by a few workers (Hyman and Southworth, 1951; Mathur, Wahi, and Gupta, 1960). The finding of haemosiderinuria in 31 out of 55 patients lends further support to the occurrence of chronic intravascular haemolysis in these patients. A study of red cell survival after tagging with radioactive isotopes might have shown an even higher incidence of haemolysis.

The presence of leucocytosis in 18 patients

TABLE V

Antierythrocyte Antibodies in Relation to Spherocytosis, Osmotic Fragility, and Degree of Haemolysis

\begin{tabular}{|c|c|c|c|c|c|c|c|c|c|}
\hline \multirow{2}{*}{$\begin{array}{c}\text { Case } \\
\text { No. }\end{array}$} & \multicolumn{2}{|c|}{ Coombs Test } & \multicolumn{3}{|c|}{ Agglutinins $\left({ }^{\circ} \mathrm{C}\right)$} & \multirow{2}{*}{$\begin{array}{c}\text { Cold } \\
\text { Haemolysin } \\
\text { with Normal } \\
\text { Cells }\end{array}$} & \multirow{2}{*}{$\begin{array}{l}\text { Sphero- } \\
\text { cytosis }\end{array}$} & \multirow{2}{*}{$\begin{array}{l}\text { Osmotic } \\
\text { Fragility* }\end{array}$} & \multirow{2}{*}{$\begin{array}{l}\text { Degree of } \\
\text { Haemolysis }\end{array}$} \\
\hline & Direct & Indirect & $4^{\circ} \mathrm{C}$ & $20^{\circ} \mathrm{C}$ & $37^{\circ} \mathrm{C}$ & & & & \\
\hline $\begin{array}{r}1 \\
2 \\
3 \\
4 \\
5 \\
6 \\
7 \\
8 \\
9 \\
10 \\
11 \\
12 \\
13 \\
14 \\
15 \\
16 \\
17 \\
18\end{array}$ & $\begin{array}{c}++ \\
+ \\
- \\
- \\
= \\
= \\
= \\
= \\
= \\
+ \\
+ \\
+ \\
+ \\
+ \\
+\end{array}$ & $\begin{array}{l}- \\
+ \\
++ \\
++ \\
++ \\
+ \\
+ \\
+ \\
+ \\
+ \\
+ \\
+ \\
+ \\
+ \\
+ \\
+ \\
-\end{array}$ & $\begin{array}{c}++ \\
+ \\
- \\
++ \\
- \\
- \\
+ \\
++ \\
++ \\
++ \\
+ \\
++ \\
+ \\
+ \\
+ \\
++ \\
++ \\
++\end{array}$ & $\begin{array}{c}- \\
+ \\
- \\
- \\
+ \\
+ \\
- \\
++ \\
+ \\
+ \\
+ \\
+ \\
++ \\
++ \\
++\end{array}$ & $\begin{array}{l}- \\
- \\
= \\
\overline{+} \\
\pm \\
= \\
- \\
+ \\
+ \\
+ \\
+ \\
+ \\
+ \\
-\end{array}$ & $\begin{array}{l}- \\
\overline{-} \\
\pm \\
= \\
= \\
\overline{-} \\
\pm \\
\pm \\
\pm \\
\pm \\
\pm \\
- \\
-\end{array}$ & $\begin{array}{c}++ \\
+ \\
+ \\
+ \\
+ \\
+ \\
- \\
+ \\
+ \\
++ \\
++ \\
+ \\
++ \\
+ \\
++\end{array}$ & $\begin{array}{l}\mathbf{I} \\
\mathbf{I} \\
\mathbf{T} \\
\mathbf{N} \\
- \\
- \\
\mathbf{N} \\
\mathbf{N} \\
\mathbf{N} \\
\mathbf{N} \\
\mathrm{T} \\
\mathbf{N} \\
\mathbf{I} \\
\mathbf{I} \\
\mathbf{I} \\
\mathbf{I} \\
\mathbf{I} \\
\mathbf{N}\end{array}$ & $\begin{array}{c}++ \\
++ \\
++ \\
+ \\
- \\
+++ \\
++ \\
+ \\
+ \\
+ \\
+++ \\
++ \\
++ \\
++ \\
+ \\
+\end{array}$ \\
\hline
\end{tabular}

$\star I$, Increased; $T$, tailing; $N$, normal. 
appears to be a response to haemolysis since patients with active infection and/or haemorrhage were not included in the present series. The leukaemoid reaction seen in 6 patients was associated with either moderate or severe haemolysis; leukaemoid reaction in haemolytic anaemia associated with liver disease has been reported by Hyman and Southworth (1951).

The degree of anaemia was not always proportional to the severity of the haemolytic process, but all patients manifesting severe haemolysis had severe anaemia as well.

Leucopenia or thrombocytopenia in the presence of normal or hypercellular marrow in patients with anaemia is taken as indicative of hypersplenism by Berman et al. (1949) and Jones et al. (1955). By these criteria evidence for hypersplenism was available in only 7 patients. Two patients with enlarged spleen and anaemia showed leucocytosis rather than leucopenia.

The degree of haemolysis appeared to increase with the fall of prothrombin index and serum albumin (Fig. 1). This observation suggests an increase in the severity of haemolysis with advancing liver failure. A similar observation has been reported by Kimber et al. (1965) in adult patients with cirrhosis of the liver.

The incidence of positive red cell serology in our patients is higher than has been reported in adult patients. According to Dacie (1967) antierythrocyte antibodies are an uncommon cause of haemolysis in liver disease, as judged from the frequency with which the antiglobulin test has been reported to be positive (Hyman and Southworth, 1951; Easton, Priest, and Giles, 1965). But Jandl (1955) and Kimber et al. (1965) were unable to demonstrate a positive Coombs test in their series of 20 and 46 patients, respectively. From the present study it is difficult to assess to what extent the antierythrocyte antibodies found in these children were responsible for the increased haemolysis. Autoimmune haemolysis appeared to be significant in only 15 of them, in whom the presence of antierythrocyte antibodies was associated with spherocytosis, red cell clumping, and increased osmotic fragility. The mechanism by which liver disease brings about the formation of antierythrocyte antibodies is not certain. It has been suggested that liver cell injury may release substances which provide the antigen initiating the autoimmunization against red cells (Beickert and Siering, 1958; Mackay and Wood, 1962).
The possibility of a haemolytic component due to intake of drugs before admission to hospital was excluded both by history as well as negative Heinz body test. We were unable to find an association between haemolysis and hypercholesterolaemia, as has been reported by Zieve (1966.)

The clinical picture of hepatosplenomegaly, jaundice, and anaemia in association with severe haemolysis usually suggests a primary haemolytic disorder, congenital or acquired. The possibility that it may be part of the clinical picture of childhood cirrhosis needs emphasis.

\section{REFERENCES}

Achar, S. T., Raju, V. B., and Sriramachari, S. (1960). Indian childhood cirrhosis. Fournal of Pediatrics, 57, 744.

Beickert, A., and Siering, H. (1958). Immunpancytopenie mit Auftreten heterophiler antikörper bei akuter Hepatitis epidemica kompliziert durch eine schwere Myocarditis. Acta Haematologica, 8, 51 .

Berman, L., Axelord, A. R., Horan, T. N., Jacobson, S. D., Sharp, E. A., and Vonder Heide, E. C. (1949). The blood and bone marrow in patients with cirrhosis of the liver. Blood, 4, 511.

Dacie, J. V. (1967). The Haemolytic Anaemias: Congenital and Acquired, Part III. 2nd ed. Churchill, London.

- and Lewis, S. M. (1963). Practical Haematology, 3rd ed. Churchill, London.

Easton, J. A., Priest, C. J., and Giles, C. M. (1965). An antibody against stored blood associated with cirrhosis of the liver and false-positive serological tests for syphilis. Fournal of Clinical Pathology, 18, 460.

Huang, K. W., and Wang, H. W. (1949). Anemia associated with cirrhosis of the liver. A study of 32 cases. Archives of Internal Medicine, 84, 958.

Hyman, A., and Southworth, H. (1951). Hemolytic anemia associated with liver disease. American fournal of the Medical Sciences, 221, 448.

Jandl, J. H. (1955). The anemia of liver disease: observations on its mechanism. Fournal of Clinical Investigation, 34, 390.

Jones, P. N., Weinstein, I. M., Ettinger, R. H., and Capps, R. B. (1955). Decreased red cell survival associated with liver disease. Use of $\mathrm{Cr}^{51}$ in measurement of red cell survival. Archives of Internal Medicine, 85, 93.

Kimber, C., Deller, D. J., Ibbotson, R. N., and Lander, H. (1965). The mechanism of anaemia in chronic liver disease. Quarterly fournal of Medicine, 34, 33.

Liver Diseases Sub-Committee (1955). Infantile cirrhosis of the liver in India. Indian fournal of Medical Research, 43, 723.

Mackay, I. R., and Wood, I. J. (1962). Lupoid hepatitis: a comparison of 22 cases with other types of chronic liver disease. Quarterly fournal of Medicine, 31, 485.

Mathur, K. S., Wahi, P. N., and Gupta, M. C. (1960). Anaemia in cirrhosis of the liver: a clinical study. Fournal of the Indian Medical Association, 35, 539.

Schoenheimer, R., and Sperry, W. M. (1963). In Clinical Laboratory Methods and Diagnosis, 6th ed., p. 252. Ed. by S. Frankel and S. Reitman. Mosby, Saint Louis.

Zieve, L. (1966). Hemolytic anaemia in liver disease. Medicine, 45, 497.

Correspondence to Dr. A. Perkash, Assistant Professor Pathology, Department of Pathology, Institute of Postgraduate Medical Education and Research, Chandigarh, India. 